\title{
SLAUGHTER VALUE OF YOUNG POLISH BLACK-AND-WHITE, WHITE-BACKED, POLISH HOLSTEIN-FRIESIAN AND LIMOUSIN BULLS UNDER SEMI-INTENSIVE FATTENING*
}

\author{
Zygmunt Litwińczuk ${ }^{1}$, Witold Chabuz ${ }^{1}$, Piotr Domaradzki², \\ Przemysław Jankowski ${ }^{1}$
}

\begin{abstract}
'Department of Breeding and Protection of Genetic Resources of Cattle, University of Life Sciences, Akademicka 13, 20-950 Lublin, Poland

${ }^{2}$ Department of Commodity Science and Processing of Raw Animal Materials, University of Life Sciences, Akademicka 13, 20-950 Lublin, Poland

Corresponding author: zygmunt.litwinczuk@up.lublin.pl
\end{abstract}

\begin{abstract}
The objective of the present study was to compare the slaughter value of young bulls of two breeds included in the genetic resources conservation programme, namely Polish Black-White and Whitebacked with young Polish Holstein-Friesian (dairy type) and Limousin (beef type) bulls. This is the first study to evaluate the meat performance traits of White-backed cattle in several-centuries history of the breed in Poland. It was determined that populations of White-backed and Polish Blackand-White cattle represent the dual-purpose type desirable in the genetic resources conservation programme. The indices obtained for the analysed traits of slaughter value from young Polish Black-and-White and White-backed bulls were intermediate between Polish Holstein-Friesian (dairy type) and Limousin (beef type), but closer to those of the Polish Holstein-Friesian breed. The analysed muscles of young bulls had a very similar content of basic chemical components. The relatively high amount of proteins (22.85-23.23\%) in musculus longissimus lumborum and in musculus semintendinosus (22.43-23.06\%) should be emphasized.
\end{abstract}

Key words: young bulls, slaughter value, cattle breeds

Young slaughter cattle are primarily fattened to produce culinary beef. Its final quality is determined by a broad spectrum of factors, including pre-slaughter factors (such as type, breed, sex, feeding system) and post-slaughter factors (such as dressing and meat ageing) (Kołczak, 2008; Litwińczuk and Litwińczuk, 1998; Miciński et al., 2005). It is assumed that the best quality meat is obtained from young animals of the beef type up to 2 years of age.

* This work was conducted as part of Ministry of Science and Higher Education, project no. N311 028334. 
Limousin is the most popular breed among beef breeds of cattle in Poland; moreover, it is involved in the commercial crossbreeding in dairy herds. Animals of beef breeds are capable of achieving the optimal level of genetic potential under full feeding conditions, i.e. intensive fattening. However, the most popular fattening system for young cattle in Poland is semi-intensive fattening and, to some extent, also the extensive system. Animals suitable for this type of fattening represent the dual-purpose type, which includes indigenous breeds of cattle (such as Polish Black-andWhite and White-backed).

The last several years were marked by rising consumer health awareness, which is reflected in the increased demand for health beneficial food characterized by high nutritional value and from a reliable source. It is without doubt that such food includes milk and meat obtained on low-input (also organic) farms, which maintain local cattle breeds. Such farms employ pasture grazing during the summer feeding season and use their own fodder (silage, hay) in the winter season (Litwińczuk, 2011). Consumers in the EU value Polish beef not only due to its competitive price, but also because of the animal husbandry system based on natural plant feed, which increases the attractiveness of the meat obtained (Florek, 2009).

The genetic resources conservation programme in Poland involves 4 breeds of cattle, including two old indigenous cattle breeds (Polish Black-White and Whitebacked) with a history of husbandry and breeding that started a few centuries ago.

The main aim of the present study was to evaluate the slaughter value of young bulls representing two breeds included in the genetic resources conservation programme, namely Polish Black-and-White and White-backed. The results obtained were related to young bulls of the Polish Holstein-Friesian (dairy type) and Limousin breeds (beef type). This is the first study to evaluate the meat traits of White-backed cattle in several-centuries history of the breed in Poland.

\section{Material and methods}

The research involved 43 young bulls maintained in 3 farms from 2009 to 2011. Eight young bulls of the Polish Black-and-White (BW) and 19 of the White-backed breeds (WB) were fattened on the first farm. Eight Limousin (LIM) and 8 Polish Holstein-Friesian animals (HF) were maintained on the second and third farm, respectively. The animals were fattened under the semi-intensive system with similar feed rations. The basic feed during summer consisted of grass forage and maize silage, whereas in the winter season it was ensiled hay and maize silage. Bulls were free to eat as much as they wanted, the proportion of the feed mixture was $1: 1$, and meadow hay (5-10\% of ration dry matter) and cereal crushed meal (15-20\% of ration dry matter) were added as a supplement.

The groups of animals for fattening control were assembled in a period of approximately 1 month. After a period of suckling, calves above the age of 3 months were placed in these groups, taking their health condition into consideration. Fattening was monitored for every breed for approximately 18 months and it ended with control slaughter in the meat plants. 
The body weight $(\mathrm{kg})$ of animals was determined prior to the slaughter and daily weight gain (g) was calculated on its basis. Slaughter and dressing were conducted in compliance with technology applicable in the meat industry and under the supervision of veterinary inspection. Hot carcass weight $(\mathrm{kg})$ and kidney fat mass $(\mathrm{kg})$ were determined. Further examinations included assessment of:

- carcass conformation score (according to the EUROP system) marked with letters $\mathrm{E}, \mathrm{U}, \mathrm{R}, \mathrm{O}, \mathrm{P}$ and divided into subclasses $(+, 0,-)$,

- carcass fat cover score (according to the EUROP system) marked with numbers $1,2,3,4,5$ and divided into subclasses $(+, 0,-)$.

The carcasses were graded by qualified classifiers within 1 hour of the slaughter.

The half-carcasses were then placed in cold storage for 24 hours at $0-4^{\circ} \mathrm{C}$. After chilling, half-carcasses were weighed in order to determine cold carcass weight $(\mathrm{kg})$. The following linear measurements $(\mathrm{cm})$ were also performed: front length and width of half-carcass, length of loin, and length and circumference of leg. Hot and cold dressing percentage $(\%)$, kidney fat percentage (\%) and leg rounding index (\%) were calculated.

Leg was separated from the right half-carcass during the dissection according to PN-88/A-82003, after which it was weighed and divided into basic elements (meat, fat, bones). All elements were weighed with the accuracy to $0.01 \mathrm{~kg}$ and their proportion in the leg was recorded.

Additionally, samples were collected from the musculus longissimus lumborum and musculus semintendinosus to determine the basic chemical composition, i.e. contents of water using the drying method $\left(103^{\circ} \mathrm{C}\right.$, according to PN-ISO 1442:2000 standard), total proteins with Kjeldahl's method using Büchi B-324 device (according to PN-75/A 04018), free fat with Soxhlet's method using Büchi B-811 device (according to PN-ISO 1444:2000), and ash with the burning method (according to PN-ISO 936:2000).

Statistical analyses were conducted on the basis of one-way ANOVA with the use of StatSoft STATISTICA ver. 6.0. The significance of differences between means in analysed groups was verified with Tukey's HSD test. For items expressed in points, Kruskal-Wallis nonparametric test was used.

\section{Results}

The type and breed of animal are among the major factors influencing the slaughter value of cattle. The average body weight of young bulls at slaughter was similar in the analysed groups and ranged from $593.2 \mathrm{~kg}$ for White-backed cattle to $619.6 \mathrm{~kg}$ for Limousin (Table 1). Additionally, daily weight gains were also corresponding as they ranged from $855 \mathrm{~g}$ to $881 \mathrm{~g}$ for HF and both local breeds (BW and WB) and $938 \mathrm{~g}$ for young LIM bulls. The differences determined between these 3 breeds and the LIM breed were statistically insignificant (which may be attributed to high standard deviation values). 


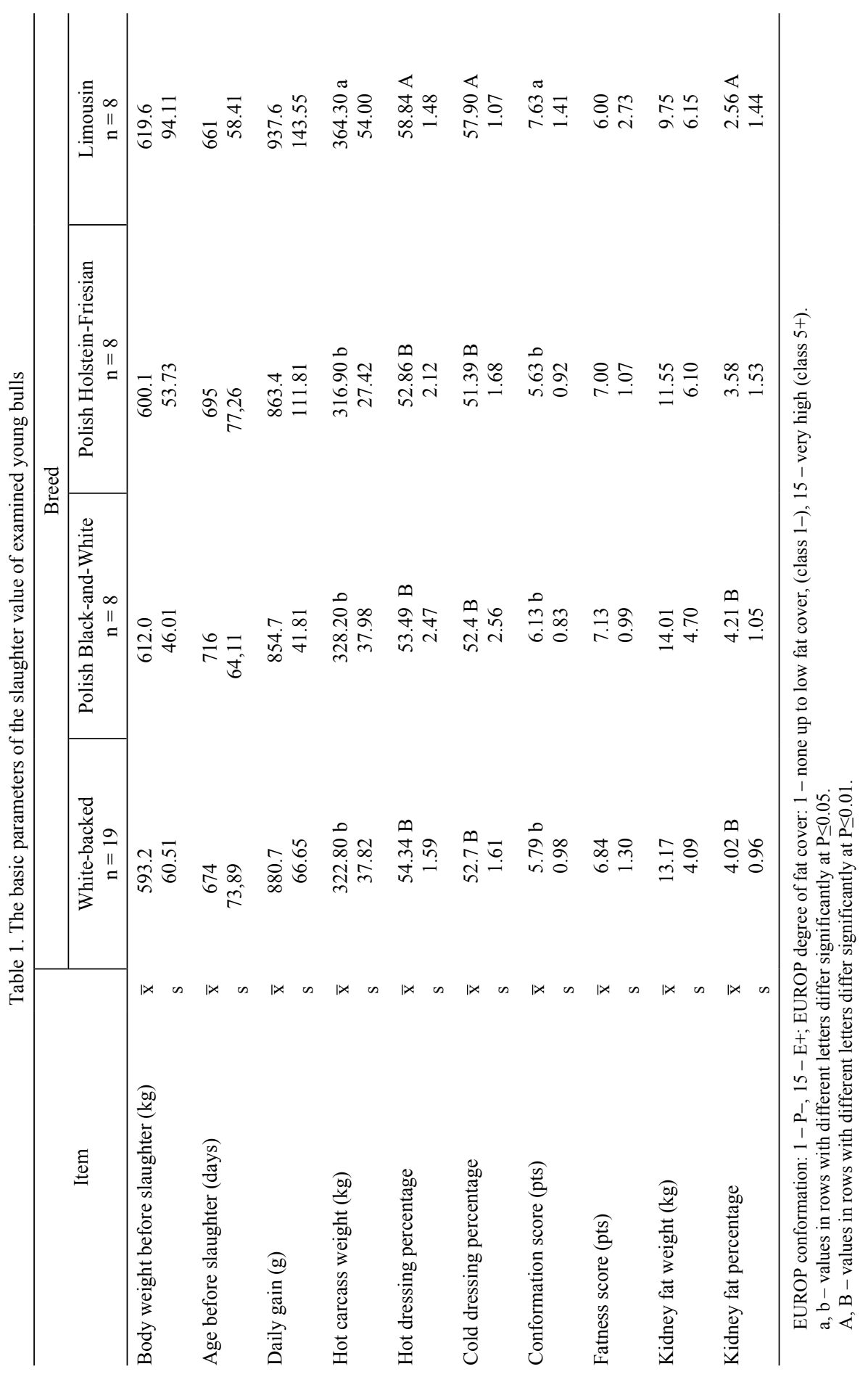


Nevertheless, significant differences between analysed breed groups were stated for the most important traits of slaughter value, namely hot carcass weight, dressing percentage, carcass conformation score and percentage of kidney fat. As expected, significantly best $(\mathrm{P} \leq 0.01$ and $\mathrm{P} \leq 0.05)$ values of these traits were recorded for young LIM bulls. The values of these traits in young bulls of two native breeds were intermediate between dairy breed (HF) and beef breed (LIM), although closer to the HF breed (the differences were statistically insignificant).

The carcass conformation score for the total number of analysed animals (43 individuals) averaged $6.16 \mathrm{pts}$ (on a 15-point scale), which is qualified as $\mathrm{R}$ - class. The highest score was observed in young LIM bulls ( $7.63 \mathrm{pts})$, and the lowest in the HF breed (5.63 pts). However, no significant differences in carcass fat cover score in EUROP system were stated for analysed carcasses. The average score for the total number of analysed animals was 6.77 pts., consistent with 3-class.

The lowest weight of kidney fat $(9.75 \mathrm{~kg})$ and its significantly $(\mathrm{P} \leq 0.01)$ lowest proportion $(2.56 \%)$ were recorded for young LIM bulls, and the highest for young BW bulls (14.01 kg and 4.21\%, respectively).

Slaughter value appears to be closely related to body weight and selected measurements of carcass. Traits such as carcass size, conformation and proportions can be estimated on this basis. The results obtained (Table 2) indicate that the carcasses of young LIM and HF bulls were the longest $(143.75 \mathrm{~cm})$, and those of BW bulls the shortest $(137.63 \mathrm{~cm})$. The chest width in all examined groups was in the range from 73.13 to $74.13 \mathrm{~cm}$. Significantly greatest length of loins was determined for young LIM bulls $(57.38 \mathrm{~cm})$. The greatest leg circumference was also observed in LIM bulls $(117.50 \mathrm{~cm})$, whereas the smallest in young bulls of the WB breed $(109.74 \mathrm{~cm})$. Leg rounding index ranged from $147 \%$ to $148 \%$ for $\mathrm{HF}$ and WB breeds and reached $155 \%$ in LIM.

Table 2. The linear measurements of half-carcasses of evaluated young bulls

\begin{tabular}{|c|c|c|c|c|c|}
\hline \multirow[b]{2}{*}{ Item } & & \multicolumn{4}{|c|}{ Breed } \\
\hline & & $\begin{array}{l}\text { White-backed } \\
\qquad \mathrm{n}=19\end{array}$ & $\begin{array}{c}\text { Polish } \\
\text { Black-and-White } \\
\mathrm{n}=8\end{array}$ & $\begin{array}{c}\text { Polish } \\
\text { Holstein-Friesian } \\
\mathrm{n}=8\end{array}$ & $\begin{array}{c}\text { Limousin } \\
\mathrm{n}=8\end{array}$ \\
\hline Carcass length $(\mathrm{cm})$ & $\begin{array}{l}\overline{\mathrm{X}} \\
\mathrm{S}\end{array}$ & $\begin{array}{c}138.00 \mathrm{a} \\
5.34\end{array}$ & $\begin{array}{c}137.63 \mathrm{a} \\
5.13\end{array}$ & $\begin{array}{c}143.75 \mathrm{~b} \\
10.07\end{array}$ & $\begin{array}{c}143.75 \mathrm{~b} \\
3.15\end{array}$ \\
\hline Chest width $(\mathrm{cm})$ & $\begin{array}{l}\overline{\mathrm{X}} \\
\mathrm{S}\end{array}$ & $\begin{array}{r}73.63 \\
2.29\end{array}$ & $\begin{array}{r}73.88 \\
2.42\end{array}$ & $\begin{array}{r}74.13 \\
3.48\end{array}$ & $\begin{array}{r}73.13 \\
3.52\end{array}$ \\
\hline Loin length $(\mathrm{cm})$ & $\begin{array}{l}\bar{x} \\
S\end{array}$ & $\begin{array}{c}39.58 \mathrm{~B} \\
1.80\end{array}$ & $\begin{array}{c}39.13 \mathrm{~B} \\
1.81\end{array}$ & $\begin{array}{c}40.25 \mathrm{~B} \\
1.83\end{array}$ & $\begin{array}{c}57.38 \mathrm{~A} \\
4.50\end{array}$ \\
\hline Leg length $(\mathrm{cm})$ & $\begin{array}{l}\overline{\mathrm{X}} \\
\mathrm{S}\end{array}$ & $\begin{array}{r}74.26 \\
4.65\end{array}$ & $\begin{array}{r}75.20 \\
4.34\end{array}$ & $\begin{array}{r}74.75 \\
3.15\end{array}$ & $\begin{array}{r}75.75 \\
3.66\end{array}$ \\
\hline Leg circumference $(\mathrm{cm})$ & $\begin{array}{l}\overline{\mathrm{X}} \\
\mathrm{S}\end{array}$ & $\begin{array}{c}109.74 \mathrm{a} \\
11.87\end{array}$ & $\begin{array}{r}114.75 \\
4.57\end{array}$ & $\begin{array}{r}110.00 \\
6.44\end{array}$ & $\begin{array}{c}117.50 \mathrm{~b} \\
3.33\end{array}$ \\
\hline Leg rounding index $(\%)$ & $\begin{array}{l}\bar{X} \\
S\end{array}$ & $\begin{array}{c}148.88 \mathrm{~b} \\
22.45\end{array}$ & $\begin{array}{r}152.83 \\
7.95\end{array}$ & $\begin{array}{c}147.51 \mathrm{~b} \\
12.19\end{array}$ & $\begin{array}{c}155.62 \mathrm{a} \\
9.48\end{array}$ \\
\hline
\end{tabular}

$\mathrm{a}, \mathrm{b}-$ values in rows with different letters differ significantly at $\mathrm{P} \leq 0.05$.

$\mathrm{A}, \mathrm{B}-$ values in rows with different letters differ significantly at $\mathrm{P} \leq 0.01$. 
Slaughter value of animals is determined by the proportion of cuts with a high retail value. Leg is considered to be one of the most valuable saleable cuts (which also include tenderloin, best rib and sirloin) obtained from bovine carcass dissection. Tenderloin weight in the evaluated young bulls (Table 3) ranged from 3.00 to $3.40 \mathrm{~kg}$ for $\mathrm{BW}, \mathrm{HF}$ and $\mathrm{WB}$ breeds and 4.60 for the LIM breed $(\mathrm{P} \leq 0.01)$ and its proportion in carcass was $1.52-2.00 \%$ for these three breeds and $2.73 \%$ for the LIM breed $(\mathrm{P} \leq 0.05$ and $\mathrm{P} \leq 0.01)$.

Table 3. The weight of tenderloin and leg and tissue composition of leg

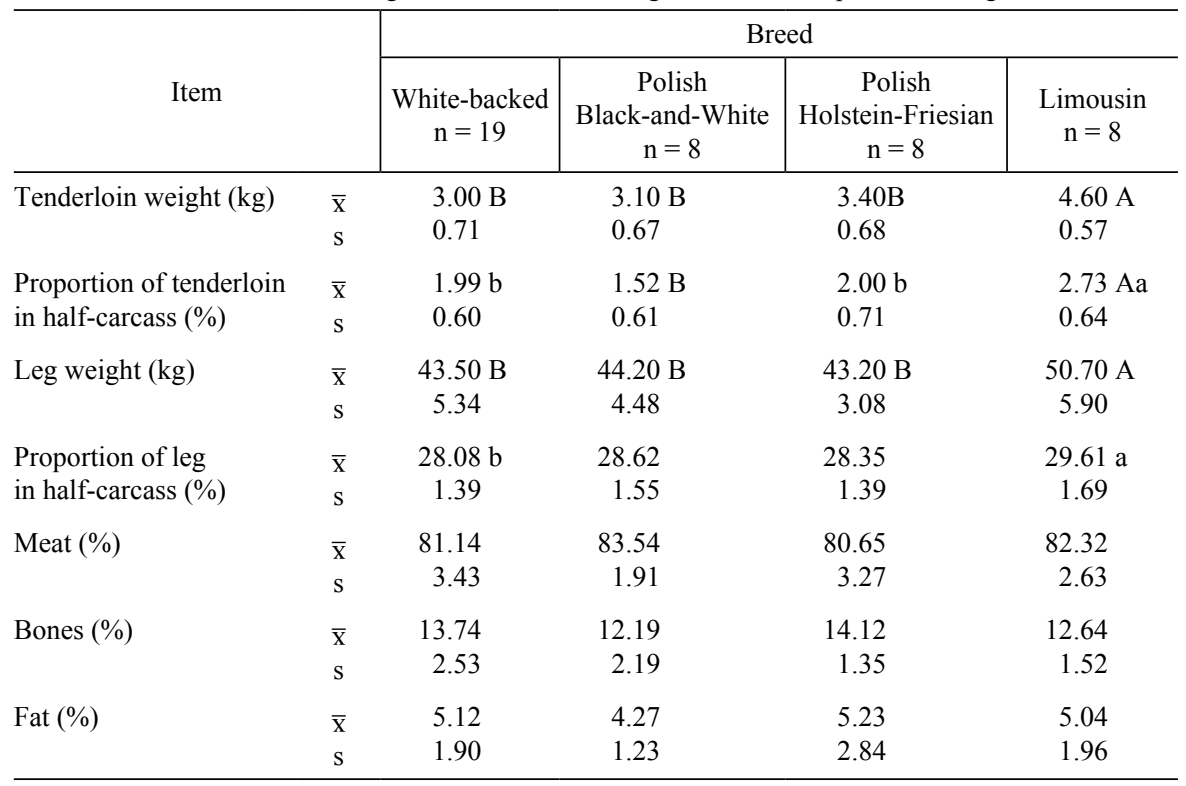

$\mathrm{a}, \mathrm{b}$ - values in rows with different letters differ significantly at $\mathrm{P} \leq 0.05$.

$\mathrm{A}, \mathrm{B}-$ values in rows with different letters differ significantly at $\mathrm{P} \leq 0.01$.

Compared with other analysed cattle breeds, young LIM bulls were characterized by the highest leg proportion in carcass (Table 3$)$ and significantly $(P \leq 0.01)$ the highest leg weight $(29.61 \%$ and $50.70 \mathrm{~kg}$, respectively). Leg weight for other investigated breeds ranged from $43.20 \mathrm{~kg}$ (HF) to $44.20 \mathrm{~kg}$ (BW), whereas its proportion in carcass ranged from $28.08 \%$ (WB) to $28.62 \%$ (BW).

The evaluated legs were characterized by a similar tissue composition (differences statistically insignificant). The proportion of meat was $80.65-83.54 \%$, that of fat $4.27-5.23 \%$, and that of bones $12.19-14.12 \%$ (Table 3 ).

Results described in Table 4 indicate that the chemical composition of both muscles obtained from all 4 breeds of young bulls was similar. The meat of young White-backed bulls had a higher content of protein (approximately $0.32 \%$ more for musculus longissimus lumborum and $0.55 \%$ more for musculus semintendinosus), but the differences were statistically insignificant. 
Table 4. Chemical composition of longissimus lumborum and semitendinosus muscles of young bulls

\begin{tabular}{|c|c|c|c|c|c|}
\hline \multirow[b]{2}{*}{ Item } & & \multicolumn{4}{|c|}{ Breed } \\
\hline & & $\begin{array}{c}\text { White-backed } \\
n=19\end{array}$ & $\begin{array}{c}\text { Polish } \\
\text { Black-and-White } \\
\mathrm{n}=8\end{array}$ & $\begin{array}{c}\text { Polish } \\
\text { Holstein-Friesian } \\
\mathrm{n}=8\end{array}$ & $\begin{array}{c}\text { Limousin } \\
\mathrm{n}=8\end{array}$ \\
\hline \multicolumn{6}{|c|}{ musculus longissimus lumborum } \\
\hline \multirow[t]{2}{*}{ Total protein $(\%)$} & $\overline{\mathrm{x}}$ & 23.23 & 22.85 & 22.94 & 22.93 \\
\hline & $\mathrm{s}$ & 0.93 & 0.41 & 0.80 & 0.49 \\
\hline \multirow[t]{2}{*}{ Fat $(\%)$} & $\overline{\mathrm{x}}$ & 1.49 & 1.55 & 1.71 & 1.40 \\
\hline & $\mathrm{s}$ & 0.47 & 0.57 & 0.42 & 0.58 \\
\hline \multirow{2}{*}{ Dry matter $(\%)$} & $\overline{\mathrm{x}}$ & 25.65 & 25.36 & 25.70 & 25.22 \\
\hline & $\mathrm{s}$ & 1.21 & 0.82 & 1.02 & 1.23 \\
\hline \multirow[t]{2}{*}{ Ash $(\%)$} & $\overline{\mathrm{x}}$ & 0.93 & 0.96 & 1.05 & 0.90 \\
\hline & $\mathrm{s}$ & 0.17 & 0.23 & 0.15 & 0.21 \\
\hline \multicolumn{6}{|c|}{ musculus semitendinosus } \\
\hline \multirow[t]{2}{*}{ Total protein $(\%)$} & $\overline{\mathrm{x}}$ & 23.06 & 22.62 & 22.47 & 22.43 \\
\hline & $\mathrm{s}$ & 0.79 & 1.29 & 0.60 & 0.76 \\
\hline \multirow[t]{2}{*}{ Fat $(\%)$} & $\overline{\mathrm{x}}$ & 0.98 & 0.94 & 1.02 & 1.12 \\
\hline & $\mathrm{s}$ & 0.39 & 0.25 & 0.40 & 0.49 \\
\hline \multirow[t]{2}{*}{ Dry matter $(\%)$} & $\overline{\mathrm{x}}$ & 24.92 & 24.54 & 24.54 & 24.43 \\
\hline & $\mathrm{s}$ & 0.97 & 1.35 & 0.82 & 0.82 \\
\hline \multirow[t]{2}{*}{ Ash (\%) } & $\bar{x}$ & 0.89 & 0.98 & 1.06 & 0.89 \\
\hline & $\mathrm{s}$ & 0.24 & 0.14 & 0.16 & 0.34 \\
\hline
\end{tabular}

\section{Discussion}

Native breeds of cattle in Poland and in Europe are the multipurpose type characterized by distinct beef traits and massive body structure. Such type of cattle allows them to be maintained in regions with adverse environmental conditions, such as mountain areas (breeds such as Reggiana, Vosgienne, Telemark, Abondance, and Polish Red) or wetlands (White-backed cattle) (FAO, 2007; Hiemstra, 2010; Litwińczuk, 2009, 2011).

The present study revealed that young WB and BW bulls were characterized by slightly better dressing percentage and better carcass conformation as compared with young HF bulls and significantly $(\mathrm{P} \leq 0.01)$ worse as compared to the LIM breed.

Considerably better carcass conformation that is characteristic of beef breeds was previously reported by Albertí et al. (2008), Clarke et al. (2009) and Dymnicki et al. (2000). All carcasses obtained from LIM bulls and evaluated by Dymnicki et al. (2000) were graded as the highest classes of carcass conformation, namely $\mathrm{E}$ and U (62.5\% and 37.5\%, respectively). Furthermore, Miciński et al. (2005) also observed remarkably high carcass conformation scores for LIM cattle (E - 63.64\% and $\mathrm{U}-36.36 \%$ ) and highlighted their superiority over young Hereford bulls. The 
results obtained in the present study for carcass conformation of HF and LIM cattle corresponded to those reported by Fabian et al. (2010) - 5.48 pts and 7.15 pts, respectively.

The literature data concerning the carcass fat cover indicate that the majority of young bulls are graded as class 2 or 3 of fat cover (Fabian et al., 2010; Florek et al., 2007; Grodzicki et al., 2010; Miciński et al., 2005; Węglarz, 2011).

The results obtained for the evaluation of slaughter value demonstrate that existing Polish Black-and-White and White-backed cattle represent the beef-dairy type, which was desirable in the interwar period (Rostafiński, 1920; Moczarski, 1927) as well as in the postwar period (Pająk, 1958).

Rostafiński (1920) and Moczarski (1927) have classified White-backed cattle maintained in the interwar period as dual-purpose type with inferior dairy traits (as compared with Dutch cattle) and superior meat traits. They also stated that this breed was preferred by farmers for draft purposes. Sasimowski (1983) reported that in terms of dairy and beef use, White-backed cattle were generally considered to be in between Polish Red and Black-and-White Lowland breeds.

The results obtained in the present study correspond with the findings of Chabuz et al. (2007), who analysed body conformation traits of local cattle breeds in Poland and stated that White-backed cattle have remarkably different body structure compared to the Polish Holstein-Friesian breed, despite considerable changes in the body structure of the existing population of White-backed cattle in Poland as compared to the 1920s (mainly an increase in frame size). Additionally, the White-backed breed is considered to be more similar to cows of the Black-and-White Lowland breed, maintained in Poland in the 1970s (Litwińczuk and Schulc, 2005) and cows of a local population of Black-and-White cattle still maintained in Eastern Poland (Litwińczuk, 2011).

Szarek et al. (1991) analysed the proportion of meat in the leg of young Polish Black-White and Polish Red-White bulls and their results correspond to the results of the present study (i.e. approximately $80 \%$ ). Data obtained by these authors concerns animals slaughtered before 1990; therefore, the animals must have represented the dual-purpose type, which is included in the current genetic resources conservation programme of Polish Black-and-White and Red-and-White cattle.

To summarize, the populations of White-backed and Polish Black-and-White cattle included in the genetic resources conservation programme, represent the dualpurpose type desirable in the programme. The values obtained for the analysed traits of slaughter value of young Polish Black-and-White and White-backed bulls were intermediate between the values obtained for Polish Holstein-Friesian (dairy type) and Limousin breeds (beef type), but were closer to the Polish Holstein-Friesian breed.

\section{References}

A 1 bertí P.,P a ne a B., S a ñ u o C.,Olle ta J.L.,Ripoll G.,Ertbjerg P., Christen se n M., Gigl i S., F a illa S., Con cetti S., H o c que t t e J.F., Ja ill er R., Ru de 1 S., R e n and G., Nute G.R., Richardson R.I., Willi a m s J.L. (2008). Live weight, body size and carcass characteristics of young bulls of fifteen European breeds. Livest. Sci., 114: 19-30. 
Chabuz W., Litwińczuk Z., S tanek P., S awicka W. (2007). Changes in body structure of the Whiteback cows over the past 80 years' time. Ann. Anim. Sci., 1 (Supl.): 49-54.

Clarke A.M., Drennan M.J., McGee M., Kenny D.A., Evans R.D., B erry D.P. (2009). Intake, live animal scores/measurements and carcass composition and value of late-maturing beef and dairy breeds. Livest. Sci., 126: 57-68.

Dymnicki E., Rek lewski Z., O prząd e k J., Słoni ew ski K., Oprzą dek A. (2000). The quality of carcasses from young bulls of beef breeds (in Polish). Zesz. Nauk. AR we Wrocławiu, 375: 113-120.

Fabian M., Strzelecki J., Lisiak B., Lisak D., Borzuta K., Janiszewski P., Grześk owi a k E. (2010). Effect of breed and category of the slaughter value of cattle (in Polish). Rocz. Nauk. PTZ, 4 (6): 295-305.

FAO (2007). The state of the world's animal genetic resources for food and agriculture. Commission on Genetic Resources for Food and Agriculture. Food and Agriculture Organization of the United Nations, Rome, 512 pp.

F lor e k M. (2009). Effect of chosen factors on calf slaughter value, physicochemical parameters of meat and its nutritional quality (in Polish). Scientific dissertations of University of Life Sciences in Lublin, 337 pp.

Florek M., Litwińczuk Z., Kędzierska-Matysek M., Grodzicki T., Skałecki P. (2007). Nutritional value of meat from musculus longissimus lumborum and musculus semitendinosus of young slaughter cattle (in Polish). Med. Wet., 63 (2): 242-246.

Grodzicki T., Litwińczuk A., Barłowska J., Domaradzki P. (2010). Slaughter value and physicochemical properties of skeletal muscles of domestic Black-and-White bullocks and commercial crosses after Limousin breed bulls (in Polish). Rocz. Nauk. PTZ, 4 (6): 295-305.

Hiemstra S. J., Ha a s Y., Maki-Tanila A., Gandini G. (2010). Local cattle breeds in Europe. Wageningen Academic Publisher, 154 pp.

K ołc z a k T. (2008). Beef quality (in Polish). Żywność. Nauka. Technologia. Jakość, 1 (56): 5-22.

Litwiń c z u k Z. (2009). Preservation of biodiversity as an important component in transmission of tradition and heritage (in Polish). Post. Nauk Rol., 1: 121-132.

Litwińczuk Z. (2011). (Editor). Protection of genetic resources of livestock and wild animals (in Polish). Warsaw, Poland, PWRiL, 295 pp.

Litwińczuk A., Litwińczuk Z. (1998). Genetic and feeding opportunities of controlling the slaughter value and meat quality in cattle (in Polish). In: Stan aktualny i perspektywy rozwoju wybranych dziedzin produckji żywności i pasz. Przemysł paszowy szansą poprawy jakości surowców zwierzęcych, J.R. Warchalewski (ed.). Poznań, Poland, Polish Society of Food Technology Publishing, Wielkopolska Department.

Litwińczuk Z., Schulc T. (2005). (Editors). Breeding and maintaining of cattle (in Polish). Warsaw, Poland, PWRiL, 412 pp.

Miciński J., Klupczyński J., Ostoja H., Cierach M., Dymnicka M., Łozicki A., Daszkiewicz T. (2005). The effect of breed and feeding of young bulls on the classification results of their carcasses under the 'EUROP' system and on the evaluation of their meat texture (in Polish). Żywność. Nauka. Technologia. Jakość, 3 (44): 147-156.

M o c z a r k i Z. (1927). Cattle breeding (in Polish). Warsaw, Poland.

P a j ą k J. (1958). The outline of cattle husbandry (in Polish). Warsaw, Poland, PWRiL.

Rost afiński J. (1920). Cattle breeding and nutrition (in Polish). Warsaw, Poland, Ksieg. Roln., $253 \mathrm{pp}$.

S a s imowski E. (1983). The outline of detailed animal breeding (in Polish), Warsaw, Poland, PWN.

Szarek J., Gil Z., Brzuski P., Z a p let a 1 P., W ęg larz A. (1991). Fattening capability and slaughter value of young bulls of Lowland Black and White and Red and White breeds (in Polish). Rocz. Nauk. Zoot., 1-2 (18): 59-67.

W ę g l arz A. (2011). Effect of pre-slaughter housing of different cattle categories on beef quality. Anim. Sci. Pap. Rep., 1 (29): 43-52. 


\section{ZYGMUNT LITWIŃCZUK, WITOLD CHABUZ, PIOTR DOMARADZKI, PRZEMYSŁAW JANKOWSKI}

\section{Wartość rzeźna buhajków rasy polskiej czarno-białej, białogrzbietej, polskiej holsztyńsko-fryzyjskiej i Limousin z opasu półintensywnego}

\section{STRESZCZENIE}

Celem pracy było porównanie wartości rzeźnej buhajków dwóch ras objętych programem ochrony zasobów genetycznych, tzn. polskiej czarno-białej i białogrzbietej z buhajkami rasy polskiej holsztyńsko-fryzyjskiej (typ mleczny) i Limousin (typ mięsny). W przypadku rasy białogrzbietej jest to pierwsza publikacja oceniająca cechy użytkowości mięsnej tego bydła w kilkusetletniej historii hodowli tej rasy w Polsce.

Stwierdzono, że populacja bydła białogrzbietego i polskiego czarno-białego reprezentuje pożądany w programie ochrony zasobów genetycznych kombinowany typ użytkowy. Uzyskane wskaźniki dla analizowanych cech wartości rzeźnej buhajków rasy polskiej czarno-białej i białogrzbietej przyjmowały wartości pośrednie pomiędzy bydłem polskim holsztyńsko-fryzyjskim (typ mleczny) i rasą Limousin (typ mięsny), jednak bardziej zbliżone były do rasy polskiej holsztyńsko-fryzyjskiej. Analizowane mięśnie buhajków wszystkich czterech ras charakteryzowały się bardzo zbliżonym udziałem podstawowych składników chemicznych. Warta podkreślenia jest stosunkowo wysoka zawartość białka: 22,85-23,23\% w musculus longissimus lumborum (w zależności od rasy) i 22,43-23,06\% w musculus semitendinosus. 